\title{
Pain and the Protagonism of Women in Parturition
}

\author{
Raquel da Rocha Pereira ${ }^{1}$, Selma Cristina Franco ${ }^{2}$, Nelma Baldin ${ }^{3}$
}

Summary: Pereira RR, Franco SC, Nelma Baldin N - Pain and the Protagonism of Women in Parturition.

Background and objectives: To understand through the theory of social representations the sociocultural dimensions of pain and its impact on the protagonism of women in parturition.

Methods: In this investigation, we used a qualitative methodology with the theoretical reference of phenomenology and the theory of social representation. Forty-five semi-structured interviews were conducted with gravidas in public and private health services of Joinville, SC, Brazil, who had at least four prenatal visits and were in the third trimester of pregnancy.

Results: From analysis of content reported in interviews, three empirical categories were formed: fears and concerns, experience, and sociocultural influence, which allowed the building of three interpretative categories: biomedical model, lack of information, and the role of women in the decision regarding the mode of delivery. The findings reported here indicate pain as one of the elements that form female social representations in parturition. It was observed that pain influences the behavior of gravidas from fear and becomes the genesis of other aversive feelings and concerns that involve parturition.

Conclusions: In this context, pain represented one of the main building blocks of female social representations on parturition, contributing to the ascending curve of cesarean section indices in Brazil.

Keywords: Labor, Obstetric; Qualitative Research; Interviews as Topic; Cesarean Section; Causality; Anthropology, Cultural.

[Rev Bras Anestesiol 2011;61(3): 376-388] @Elsevier Editora Ltda.

\section{INTROUCTION}

Unlike pregnancy in which a long period favors the gradual adaptation to changes, labor is characterized as an event that causes abrupt and intense changes with some levels of symbolism such as the intensity and unpredictability of pain, causing suffering, anxiety, and insecurity ${ }^{1}$.

In the history of anthropology, cultural interpretation of pain goes as far as primitive and archaic mythologies that had a dualistic concept: good and evil. Primitive humans were part of environmental ecology and they associated pain to evil and suffering considering it as "something from evil", which causes harm ${ }^{2}$. However, understanding the dimensions of pain and how it is processed, and its impact on social and cultural issues linked or not to the anatomical and physiologic elements involved has been the great challenge of science.

Received from the Universidade da Região de Joinville - UNIVILLE, Brazil.

1. Health and Environment; Physician; Anesthesiologist at CET/SAJ/SBA/MEC; Centro Hospitalar de Unimed and Maternidade Darcy Vargas, Joinville - SC

2. Child and Adolescent Health; Professor of UNIVILLE

3. PhD in Education; Professor of the Master's Degree Program on Health and Environment of UNIVILLE

Submitted on November 9, 2010.

Approved on December 7, 2010.

Correspondence to:

Dra. Raquel da Rocha Pereira

Rua Presidente Nasser, 307

Glória

89201835 - Joinville, SC, Brazil

E-mail: pereiras@netkey.com.br
Nevertheless, despite advances pain still does not occupy its true scientific and social space. Some studies support the need to demystify the punitive vision of pain in Western culture revealing its social role ${ }^{3}$.

Physically, pain is a physiological expression of injury or defense when facing a real aggression or with similar potential, but the individual's expression and reaction to pain has an emotional and social interpretation formatted by culture ${ }^{4}$.

Culture is responsible for the type and behavioral response to pain in which each social group and sometimes even the family has its own social representation formalizing a unique language. To know whether an individual is in pain it is necessary that he/she expresses it, make it public, share, and show a verbal or non-verbal expression ${ }^{5}$.

Representations are social interpretations imposed to the individual through social interaction and transmitted by successive generations. All classification systems, images, and descriptions of a society including scientific are a consequence of prior systems and images, i.e., a cutout or reproduction of the collective memory language, which invariably derives from an acquired knowledge ${ }^{6}$.

The social representation of parturition identifies it as a painful period of the pregnancy physiological process, and the behavioral response is influenced by both the emotional and environmental dimensions. Social and cultural factors interfere on how gravidas feel and interpret the parturition process ${ }^{1}$.

In Brazil, normal delivery is associated with pain and suffering which, due to the physiologic character of the event, imposes to women a behavior of overcome the pain of labor. Socially interpreted as "physiological", i.e., as part of the event 
nature, it generates affective, emotional, and metabolic conflicts, exposes the perceived fragility of women and favors a female representation of labor based on fears and myths such as the belief that a scheduled cesarean section will provide "labor without pain" 7.

Foucault denounces the power of physicians and the medicalization of life and culture which under the label of scientism are diffused by the media to seduce the consumer 8,9 . The culture of childbirth in contemporary Western obstetrics derives from Descartes' dualism of mind and body, the body seen as a machine under the domain of science. In this sense the culture of "cesarean section by request" seems to have been built on the social representations of physicians, but as technical professionals they should solve and not justify events ${ }^{10}$.

In Brazil, the rate of cesarean sections has been gradually increasing, especially among women with a private health plan, as demonstrated in data from 2003 to 2006, in which the rate of cesarean sections increased from $64.30 \%$ to $80.72 \%$ respectively, levels considered well above the $15 \%$ recommended by the World Health Organization (WHO), and approximately twice as high as the national mean and the most elevated worldwide ${ }^{11}$.

A study performed by the Brazilian National Supplementary Health Agency (ANS) concluded that two thirds of women with health insurance in the beginning of pregnancy wanted a normal delivery. Several factors are probably involved in this gap between the wishes of women in early pregnancy and the delivery route actually performed. According to the assistant manager of ANS, Martha Oliveira, the myth of painful or traumatic delivery versus state-of-the-art technology with competent physicians and safe hospital, attributed to normal delivery and cesarean section, respectively, is intensely present. Such myth originated or became a reality with the help of the media. Still, physicians' education encourages cesarean sections which is less labor intensive and faster than normal delivery, also implying an economical issue for physicians ${ }^{11,12}$.

The media, as well as the information and/or symbolical content it propagates, are the building blocks of social representations and can be a mechanism of power ${ }^{13}$.

Labor pain involves complex neurobehavioral responses to algogenic stimuli and provides a personal and unique characteristic to the pain felt. The cause-effect relationship in this situation does not always correspond to a clinical response, as what matters in this case is to understand the pain felt by the gravida and ameliorate it 7 .

Manzoni and Carvalho reported that pain often manifests itself even in the absence of tissue aggression. What matters is the "person who feels the pain and not the pain itself". When considering the phenomenon nature, caregiving is best directed to understand the event complexity and the individual interpretation of the pain felt and its causes. Therefore, taking into account the conceptual validity of labor pain and its multidimensional aspects may also allow offering relief interventions capable of behaving as impulse competitors in the central nervous system ${ }^{14}$.

The objective of the present study was to understand the phenomenon and cultural dimension of pain, as well as the influence of the biomedical model and the media as builders of the social representation of pain during labor.

\section{METHODS}

\section{Methodological Choice}

This study uses the theoretical-methodological design of the qualitative-phenomenological study on protagonism and decisions of the women interviewed in the parturition process and from the theory of social representation allowed the understanding of the pain phenomenon and its social and cultural influences.

The methodological analysis of the qualitative study is concerned with "a level of reality that cannot be quantified" 15 .

Phenomenology seeks to establish and combine human attitudes or traits in a rigorous and intelligible way, and only through experience one can experiment reality. In this sense the phenomenon essence is understood through the social representations manifested in the patients' discourse which were analyzed under the protection of contents analysis ${ }^{16}$.

The Social Representation Theory is concerned with the individual contribution for building a collective knowledge that orients and interprets social behaviors. These behaviors are manifested through actions, speech, and conducts because they are institutionalized, accepted, and incorporated into daily life. Therefore, they are the raw material both for analysis of transforming social facts and pedagogic and political actions ${ }^{6,15}$.

\section{STUDY POPULATION AND SELECTION PROCESS}

Forty-five women in last trimester of pregnancy were interviewed during their prenatal examination in the town of Joinville, Santa Catarina, Brazil. The interviews were performed in public clinics (Group I, with 20 gravidas) and in two private clinics (Group II, with 25 gravidas) with obstetricians as part of the assistance teams for pregnant women.

This was a convenience sample, considering the "saturation point" which is set when the interviewer noticed that no new information would be gathered. In this study the saturation point was different in each group with 20 interviews in the public service and 25 in the private service.

Selection criteria included gravidas in the third trimester; aged 18 years or older; on prenatal care having attended at least four appointments before the interview, and who accepted the invitation to participate. Gravidas who presented clinical and emotional conditions that might interfere with their cognitive capacity were excluded.

Pregnant women selected were interviewed individually by the investigator, which allowed more proximity to the described phenomenon, both through their speech and gestures, allowing deeper understanding of what these women were talking about ${ }^{17}$. 
The study followed measures to preserve confidentiality, anonymity and privacy of those interviewed. The full name of the women interviewed was restricted to the Informed Consent which they signed. Methodological measures applied were explained to them individually including the possibility of interrupting the interviewee, answering or not the questions, and having the right to refuse to participate. This study was analyzed and approved by the institution's Ethics Committee.

\section{RESEARCH INSTRUMENT}

The research instrument was a semi-structured interview script with 15 open questions, which were recorded and integrally transcribed. These questions allowed formulation of others questions that during the study were important to clarify the study objective. In other words, in qualitative methodology the interview is not rigid and flexibility is fundamental for grasping the individual point of view, which does not mean absence of methodological rigor.

Note that we tried to match the patient's language in the process of elaborating the questions. Therefore, we avoided the use of medical terminology which is often an obstacle to understanding the physician-patient dialogue.

A pretest was performed to adequate the vocabulary, determine the answers content, observe the time spent, and other logistic questions.

\section{Data Analysis}

The revealing potential of speech (regarding structural conditions and system of symbols, values, and rules) is a privileged instrument for gathering information since it can contain the experience and consequently allow intersubjective comprehension. Thus, after their transcription the data and information collected on the speech of gravidas were analyzed regarding their contents based on social representation theory. We explored structures considered relevant by patients. The non-verbal cues expressed by respondents were taken into account when collecting and analyzing data ${ }^{15}$.

\section{RESULTS AND DISCUSSION}

\section{Pain and Life Experience: Genesis of Fears and Concerns}

Fear of pain was strongly represented in the minds of the interviewed women and with the proximity of birth it becomes the genesis of other fears: fear of labor; fear of performance and to affect fetal well-being; fear of anesthesia; and fear of the unknown, among others. These fears, usually associated with stories of other women, provide emotional subsidies for gravidas to "request cesarean section": "[...] I am afraid of normal delivery because everyone says that they experienced a lot of pain and that this pain is worse than any other.
So, I tell my mother I want to have a cesarean section" (D., 22-year-old).

However, the experience of prior deliveries has proven to be a strong element influencing current decision on route of delivery. If she had a positive experience, this is her first choice: "It was a very good experience, very nice. I tell everyone that, if it depended only on the delivery, I would have 10 children. It was very nice [...]" (P. S., 29-year-old). If the experience was negative it leaves scars that reinforce fears and concerns ${ }^{10}$ : "It was horrible! I am very afraid of delivery [...] I am very afraid, I cannot eat or sleep [...] Everything is associated with fear. I think I was traumatized that day" (J., 30-year-old). Pain, defined as "an unpleasant sensorial and emotional experience", becomes one of the main reasons for fear and concerns in parturition. It exposes the psychological aspects and the painful experience dimension, as well as emotional responses and depending on the individual's cognitive, cultural, and behavioral perception there is dissociation between the individual's perception and reaction/response to nociceptive stimuli ${ }^{7}$.

The subjective interpretation of pain during labor is one of the building elements of the social representation of Brazilian women about childbirth: "My biggest fear is the pain, and not supporting it, and having to take anesthesia [...] The expectation is this: will I be able to withstand the pain?" (A. T., 36year-old).

Tokophobia is the term used to define the exacerbated fear of childbirth that becomes a psychological fear usually generated from unsuccessful prior experiences and suffering during labor such as instrumental and traumatic labor often without the aid of labor analgesia ${ }^{18}$.

In contemporary women fear of suffering triggered by pain reverberates on her protagonism as she fears for her performance, i.e., not corresponding to the female function of "being a mother". These fears assume a huge dimension, inhibit the affective-emotional sensitivity, and deviates the woman from the true meaning of motherhood ${ }^{19}$. [Motherhood: a process constructed by the mother to fulfill the needs of the newborn; it depends, primordially, on the feelings the mother can develop upon the birth of her child ${ }^{19}$ ].

Social representations on parturition congregate several contents that ultimately are always symbolized by apprehension, doubts, and the greatest of them all: fear of pain and its repercussions which makes the woman a hostage. The last trimester of pregnancy is characterized by an increase in the levels of anxiety due to the proximity of labor. Gradually increasing, this expectation increases considerably in the days before the probable due date. Therefore, this period is characterized by several fears that surround and debilitate the woman ${ }^{1}$.

In this sense, labor analgesia has been an ally of women contributing with more successful labor experiences - they feel safe without the "rule of pain", as stated by one of the interviewed women who had a previous labor with analgesia: "[...] On my first delivery, I was very afraid of normal labor. But I consider it the best delivery I had; and now, on my second time, I also want a normal delivery with analgesia [...]" (F., 24-year-old). 


\section{Social Representation of Pain and the Media}

Regarding the interpretation and understanding of perception by the women interviewed, it is important to mention MerleauPonty: "Significant intention occurs in a body and knows itself, searching for an equivalent in the available signification system that represent the language I speak and the set of written works and culture that I inherited". That is, it is understood that people know themselves when they seek to know the signs of their speech, writings, and culture to which they belong ${ }^{16}$.

And regarding the unknown or not experienced the little and insufficient information gives rise to convictions and myths that are filled with reports of other women about their experience, which are corroborated by the influence of the media and by the technical assistance of the biomedical model. "That is how I see it. It is a matter of concern with normal delivery pain of; we do not want to feel pain. You start to hear other women saying that it hurts very much. So you are uncertain, although we know that normal delivery is better because recovery is faster. Nowadays, with the advancement of medical technology, you end up deciding for the more technological than the emotional. That is how I see it" (P., 34-year-old).

Social behavior is a symbol whose response represents the results of attitudes and expressions that form value codes and systems whose significance constitute the language created from social relations and individual contribution ${ }^{6}$. As this primipara justified her option for cesarean section: "I am having a cesarean section because I am afraid of the pain; we hear people saying the pain is unbearable. It is partially my mother's fault; we grew up hearing her say that, and we end up believing that labor pain is terrible" (E., 26-year-old).

The social representation of women on parturition associates the concept of suffering and pain with normal delivery, a situation that with the event proximity frightens and debilitates women. Feelings reflect the meanings of her environment, they are echoes of cultural concepts about labor stimulated by disinformation, the media, reports of other women, and the obstetric care model ${ }^{6,10}$.

Empowered by the media, suffering and pain are in the imagery of Western society, associated with disease whi$\mathrm{ch}$, in turn, demands medical treatment. Perhaps there is a strengthening of this imagery due to the lack of information on parturition process ${ }^{13}$.

Some reports indicate the influence of media in the construction or symbolic reinforcement of fear of labor pain and the facility and safety of cesarean section. Questioned about the media influence, one woman interviewed stated: "I think it influences because, in normal delivery, even in the movies the woman is suffering, all sweaty, screaming, making a scandal in the hospital. But the same does not happen in cesarean section. If you watch a soap opera, the woman is laying there, smiling, holding the child and talking to her husband, as if everything were perfect and she was not in any risk" (F. S., 29-year-old).

In Brazil, the soap operas socially consolidates a concept without scientific basis that cesarean section is a safer procedure than normal delivery, as it can be scheduled and free women from the suffering inflicted by labor pain. This interviewee translates the influence of soap operas: "[...] It influences so much that I think most people are afraid of normal delivery because they see women screaming, everybody suffering, while in cesarean sections, they do not show anybody suffering [...]" (E, 26-year-old).

Television conveys what the market aspires, as it is the best representation of a mass communication vehicle. As organizer of daily life and social imagination, the media rapidly incorporates the demands. It is capable of perceiving what society signals and, even before society reclaims it incorporates such signals, technically reprocesses them, ideologically recycles them, and spreads them all 20 .

Another gravida reported a strong influence of the media especially for those who do not have much information: "The media influences on any subject, especially people who do not have much information or other means of information, people with little education believe the message is truth, as it is their only means of information" (R. M, 35-year-old).

\section{Social Representation on Labor}

An internal conflict can be observed in which all influencesand distortions, apprehensions and fears play a role; most interviewees have said they prefer normal delivery. Their statements reveal an intrinsic and physiologic female desire for normal delivery as stated by one interviewee: "I am afraid of the pain of normal delivery, but, since it is natural, something from nature, I prefer it" (C. G., 30-year-old).

Anthropologists studying the subject state that the preference for normal delivery seems to be related to an informal and naturalistic fallacy. [Informal fallacy according to Heemann is an idea of great persuasive strength that based on beliefs uses the logic of seduction with respectable words and desirable values to convince. Naturalistic fallacy is based on the "laws" of nature, i.e., ethical norms that would be extracted from nature]. The women's statements reveal that the option for normal delivery is due to an imposition of the "female destiny" and not by conviction that this is the best type of delivery ${ }^{21}$. This idea is offered by the pro-normal delivery discourse; but what are the repercussions for the well-being of women? Maybe it is a sexist view since it requires women to withstand pain in a primitive and cultural context, to be the provider of a life and deny her personal characteristic ${ }^{22}$.

Some of the women interviewed defended the view of resilience as a female element of bestowal: [...] Because normal delivery is the way it is; you have to feel something. To be a mother you have to feel pain, I guess" (J., 25-year-old). A statement that considers labor pain as a "passport" that legalizes the rightness to be a mother and binds the idea of heroism to the notion of women becoming mature. A culture of resilience that began when religion declares, on maternity, that mothers are models of perfection and when women overcome the suffering and adversities imposed by labor pain, they are granted the right to have the joy to be a mother: "to suffer in paradise" 23 .

Despite changes in social behavior of modern women, female questions such as the feelings involved in maternity are still present in the speech of some women and are similar to that of their ancestors. According to Beauvoir, Western wo- 
men want their performance as housewife, wife, woman, and mother to be noticed by others as perfect 25 .

This idealized mother of the collective imagery, as the "Queen of the home" lives a conflicting reality with today's real women, i.e., the professional and mother who struggles in the labor market for survival. She moves away from the maternal model of the past, represented by giving, dedication, and patience leading to a conflict with current values present in everyday life of modern women such as planning, organization, practicality, and technology representing a safety factor and time optimization 22 .

In summary, the belief of women regarding their role in the world and childbearing will reflect the social and cultural contexts lived as woman and parturient, confirming that labor pain is a consequence of physiological, psychological, and social and cultural aspects 24,25 .

\section{Social Representation of Physicians Facing Pain}

In the historical process of society, childbirth is no longer a private women's event. It became an institutionalized event filled with technological innovations aimed at technical care in which the physician is the sponsor ${ }^{25}$. Culturally, society gives credit to the model of care centered on the specialist focusing on safety that permeates expectations and influences decisions about the choice of delivery ${ }^{17}$ : "My problem is the pain [...] to know whether I can withstand it, will it be good for the baby? I want... regardless of the type o labor, I want the best for my baby" (J., 31-year-old).

The intrinsic relationship between pain, labor, and suffering, a purely social concept, originates from myths, prejudice, and absence of information, and it is closer to a primitive discourse and even inhumane practices. In this sense verbal communication and reciprocity between physician-patient occurs through an interaction between patient suffering and medical knowledge which starts by language ${ }^{8}$.

In Brazil the lack of information during prenatal period, model of care, and hospitalization for childbirth transfer to the physician the power and decision on the parturition process and symbolically creates "outsourcing of labor", i.e., a cultural phenomenon that transfers control of physiological nature from women to the technical control of the physician.

Analysis of the interviews shows lack of communication between pregnant women and physicians on questions about labor. When asked whether they considered the information given during prenatal care to be enough some interviewees reported dissatisfaction with the limited information provided by physicians. The hierarchy established between physician and patient seems to bother them, such as the case presented ahead in which the interviewee questions and reports a prior event in which the physician refused to give information. This situation demonstrates a typical power relationship. When asked whether the information provided by the physician were enough, she answered: "No, we have to look for it elsewhere." And she added: "With my first child, this bothered the physician... I wanted to talk about types of delivery, and he would say: 'It is too early'. I replied 'But I want to talk, I have so many questions to ask you [...]'. And he would say: 'It is too early", He kept postponing [...] this made me change physician" (P. S., 29-year-old).

In the public system medical information is even more difficult. The discourse is repeated and passively accepted by gravidas, who seek support in other types of knowledge: "[...] Look, what I know today I learned by myself, asking others. The physician is not of any help" (J., 30-year-old).

The social representation of physicians is based on the Cartesian paradigm of scientific medicine, which represents the "truth" and they should not be questioned ${ }^{26}$. It is a culture in which the scientific knowledge of the technical model favors a segmented and interventionist obstetric care with little dialogue that seeks to adequate routines, protocols, and computerized processes to the dynamic, physiologic, and affective process of parturition. This representation influences the decision-making power of women who in the name of safety delegates the process control to the specialized professional: "[...] He the obstetrician) will show the way, he studied for this, he knows when the baby reacts to certain situations [...] He does influence the decision: 'By principle, you are having a normal delivery! But we will talk again a little closer to the due date' - my doctor told me." (A.D., 31-year-old).

Fear of pain and misinformation are physicians' strong elements of persuasion for women's passive acceptance of cesarean section. When asked by the physician about her preference, one of the interviewees said: "[...] If a normal delivery means suffering, I do not want it; I'd rather have a cesarean section. Then he said: 'If you want, we can schedule the cesarean section tomorrow. But you do not have to answer now. Go home, think about it, and then you call me'[...]" (S., 28-year-old).

In the United States patients cannot ask physicians to apply an unnecessary of potentially harmful therapy. In the U.S. debates about cesarean section on maternal demand are an ongoing issue. There are controversies on the subject, as one of the main guidelines of obstetric care in the country is based on the physician's commitment to contribute for empowering gravidas to make a conscientious decision not based on fear. Their relationship is based on respect and commitment to educate for a shared and conscientious decision about the responsibilities of the chosen procedure ${ }^{27}$.

Fear of not being able to withstand the suffering, not being able to cope with the process and harming their baby are the main concerns of gravidas, contributing for an interventionist conduct of the physician as means of alleviating their fears especially when they assume proportions involving the entire perception of women about parturition: "[...] I am afraid of the pain, suffering, everything. Since I do not know how it will be, I have this concern of knowing how it will be, if I will be able to withstand it [...] I have never been through this before and, for this reason, I do not know how to explain what I am feeling" (C.G., 30-year-old).

On the other hand, some interviewees assume the lack of preparation to face the primitivism of maternal suffering from pain. With approval of the specialist, they expose the reality 
of our century: "[...] Suffering labor pain in the XXI century is not a modern thing [...] But I believe that society passes it to you, that cesarean section is more tranquil". Asked whether cesarean sections better represent the current culture of society, she answers: "Definitely; the fact that you do not want to wait a long time to feel all that pain. I also think that current convenience leads to it. Because I think in the old days cesarean section was not available like it is nowadays. It was a last resource, whenever some complications developed; but not nowadays. I talked to my doctor. I told him that I want cesarean section. And he answered: 'OK. Cesarean section it is'. So, it is easier." (E., 26-year-old).

To pregnant women the physician's agreement in a short and straight answer has a symbolism of the "truth of scientific knowledge", and reinforces the social representation that childbirth is a painful unnecessary step and that to avoid it cesarean section is the best option. Unfortunately, in our procesarean section culture very few professionals adopt educational and women empowering conducts to make a conscientious and shared decision.

Modern society seeks to repress the horror to danger and silence fears that cannot be avoided. Life in fear is more tolerable in silence, unnoticed, invisible. Therefore, pain, its reflexes, and the fears it triggers are not considered problematic enough by the biomedical model, which seems to use cesarean sections as a technique to silence and soothe the fears of the social representation of pain during labor ${ }^{28}$. In this context the conjecture that pain is the root of all fears and concerns of gravidas in which the lack of knowledge of its impact on labor, repercussion on fetus, and the technical support of relief is confirmed. One can conclude that lack of information and the hospital obstetric care model centered in the physician's figure, with media reinforcement of reports from other women, are the building blocks of fear on the speech and non-verbal expression of most pregnant women interviewed.

Figuratively speaking fear of pain and its repercussions are symbolically solidified in the figure of a "monster" that "undermines" the physiological process stains the pleasurable feeling of being a mother, and removes the ability of pregnant women to exercise their conscious protagonism, distancing them from feelings of motherhood that signal the true meaning of parturition, the pleasure of generating a life. Fear demands social and cultural interpretations and provides a cultural identity to the pain of suffering and resilience. This, in agreement with the biomedical model and media, creates an obstacle to the protagonism and influences women's decision.

In conclusion, it was observed that pain has the power to influence the behavior of gravidas and becomes the genesis of other aversive feelings and concerns involving parturition. 


\section{REFERENCES / REFERÊNCIAS}

01. Maldonado MTP - Aspectos Psicológicos da Gravidez do Parto e do Puerpério, em: Maldonado MTP - Psicologia da Gravidez, 16a Ed. Petrópolis, Vozes, 2002;48-60.

02. Teixeira MJ, Okada M - Dor: Evolução Histórica dos Conhecimentos, em: Teixeira MJ - Dor: Contexto Interdisciplinar. Curitiba, Ed. Maio, 2003;15-51.

03. Guerci A, Consigliere S - Por uma antropologia da dor: nota preliminar. Ilha Rev Antropol, 1999;1:57-72.

04. IASP - International Association for the Study of Pain. Disponível em: <http://www.iasp-pain.org>. Acessado em 18 março 2010. 
05. Zola IK - Culture and symptoms: an analysis of patients' presenting complaints. Am Sociol Rev, 1966;31:615-630.

06. Moscovici S - O Fenômeno das Representações Sociais, em: Moscovici S - Representações Sociais: Investigações em Psicologia Social, 6a Ed. Petrópolis, Vozes, 2009.

07. Pereira RR - Anestesia e Analgesia de Parto: Impacto na Amamentação, em: Carvalho MR, Tavares LAM - Amamentação: Bases Científicas. 3a Ed. Rio de Janeiro, Guanabara Koogan, 2010;138-139.

08. Foucault M - Poder - Corpo, em: Foucault M - Microfísica do Poder. 25a Ed, São Paulo: Graal, 2008;151-152.

09. Martins A - Biopolítica: o poder médico e a autonomia do paciente em uma nova concepção de saúde. Interface Comun Saúde, Educ, 2004;8:21-32.

10. Helman CG - Dor e Cultura, em: Helman CG - Cultura, Saúde e Doença. 5a Ed, Porto Alegre, Artmed, 2009;155-174.

11. Dias MAB, Domingues RMSM, Pereira APE et al. - Avaliação da Demanda para Cesariana e de Adequação de sua Indicação em Unidades Hospitalares do Sistema de Saúde Suplementar do Rio de Janeiro, em: Agência Nacional de Saúde Suplementar (Brasil) - O Modelo de Atenção Obstétrica no Setor de Saúde Suplementar no Brasil: cenários e perspectivas. Rio de Janeiro, ANS, 2008;95-126.

12. Jungmann $M$ - Mulheres mudam de ideia durante gravidez e preferem cesariana, diz pesquisa. Disponível em: <http://cienciaesaude. uol.com.br/ultnot/2008/05/07/ult4477u595.jhtm>. Acesso em 07 maio 2008.

13. Thompson JB - A Mídia e a Modernidade: uma teoria social da mídia. 5a Ed. Petrópolis, Vozes, 2002;42-74.

14. Mazoni SR, Carvalho EC - Dor de parto: considerações históricas e conceituais. Rev Dor, 2008;9:1176-1182.

15. Minayo MCS - Técnicas de Análise do Material Qualitativo, em: Minayo MCS - O Desafio do Conhecimento: Pesquisa Qualitativa em Saúde. 11ª Ed, São Paulo, Hucitec, 2008;303-327.

16. Merleau-Ponty $M$ - O Problema das Ciências do Homem segundo Hussel, em: Merleau-Ponty M - Ciências do Homem e Fenomenologia. São Paulo, Saraiva, 1973;28-33.

17. Geertz C - Uma Descrição Densa: Por uma Teoria Interpretativa da Cultura, em: Geertz C - A Interpretação das Culturas. Rio de Janeiro: LTC, 1989;10-11.

18. Hofberg K, Brockington I - Tokophobia: an unreasoning dread of childbirth. A series of 26 cases. Brit J Psychiatry, 2000;176:83-85.

19. Odent M - A Abordagem Etnológica - Comparando Culturas, em: Odent M - A Cientificação do Amor. Florianópolis, Saint Germain, 2002;13-17.

20. Sodré M - Sobre a Mídia. Rio de Janeiro, Eco, 1993; 9-25.

21. Heemann A - A Controvérsia sobre os Alicerces da Conduta Humana, em: Heemann A - O Corpo que Pensa: Ensaio sobre o Nascimento e a Legitimação dos Valores. 2a Ed, Curitiba, Guerreiro Editora, 2005;71-77.

22. Badinter E - As Distorções entre o Mito e a Realidade, em: Badinter E - Um Amor Conquistado: O Mito do Amor Materno. 9a Ed, Rio de Janeiro, Nova Fronteira,1985;331-333.
23. Beauvoir S - Situação - a Mãe, em: Beauvoir S - O Segundo Sexo: A Experiência Vivida. 2a Ed, Rio de Janeiro, Nova Fronteira, 2009; 682-683.

24. Griboski RA; Guilhem D - Mulheres e profissionais de saúde: o imaginário cultural na humanização ao parto e nascimento. Texto Contexto Enferm, 2006;15:107-114.

25. Almeida NAM, Soares LJ, Sodré RLR et al. - A dor do parto na literatura científica da Enfermagem e áreas correlatas indexada entre 1980-2007. Rev Eletr Enf, 2008;10:1114-1123. Disponível em: < http://www.fen.ufg.br/revista/v10/n4/pdf/v10n4a 24.pdf>. Acesso em: Acesso em 07 maio 2008.

26. Spink MJP - Psicologia da Saúde: A Estruturação de Um Novo Campo de Saber, em: Spink MJP - Psicologia Social e Saúde: Práticas, Saberes e Sentidos. 6a Ed, Petrópolis: Vozes. 2009;29-34.

27. Williams $\mathrm{HO}$ - The ethical debate of maternal choice and autonomy in cesarean delivery. Clin Perinatol, 2008;35:455-462.

28. Bauman Z - Sobre a Origem, a Dinâmica e os Usos do Medo, em: Bauman Z - Medo Líquido. Rio de Janeiro, Zahar, 2008;7-20.

Resumen: Pereira RR, Franco SC, Nelma Baldin N - El Dolor y el Protagonismo de la Mujer en el Parto.

Justificativa y objetivos: Comprender, por medio de la teoría de las representaciones sociales, las dimensiones socioculturales del dolor y su impacto en el protagonismo de la mujer en el parto.

Método: Para la investigación, se usó la metodología cualitativa, con el referente teórico de la fenomenología y de la teoría de la representación social. Se hicieron 45 entrevistas semiestructuradas con embarazadas de los servicios público y privado de salud de Joinville, SC, con el mínimo de cuatro consultas de prenatal y que estaban en el tercer trimestre de gestación.

Resultados: Del análisis de contenido de los testimonios, surgieron tres categorías empíricas: miedos y preocupaciones, y vivencias e influencia sociocultural, que posibilitaron construir tres categorías interpretativas: modelo biomédico, falta de información y el rol de la mujer en la toma de decisión por el parto. Los hallazgos relatados en este artículo, indican el dolor como siendo uno de los elementos constitutivos de las representaciones sociales femeninas sobre el parto. Vimos también que el dolor influye en el comportamiento de la embarazada a partir del miedo y se convierte en la génesis de otros sentimientos de aversión y en preocupaciones que involucran el evento del parto.

Conclusiones: En ese sentido, el dolor se revela como siendo uno de los principales constructores de las actuales representaciones sociales femeninas sobre el parto y contribuye para la curva ascendente en los indicadores de cesárea en Brasil.

Descriptores: ANALGESIA, Parto; CIRUGÍA, Cesárea. 